\title{
Pendekatan Lintas-Budaya untuk Penyempurnaan Kurikulum di SMK Plus Bina Nusantara Mandiri Pariaman
}

\author{
Mustafa Zen \\ STIA BNM Pariaman, Kopertis Wilayah X Sumatera Barat, Indonesia \\ Email: mustafazen31@gmail.com \\ Hp: 08126798055
}

\begin{abstract}
Diversity in the context of curriculum planning (students' social, cultural, political affiliation and economic, does not only have a direct influence to teachers' ability in carrying out the curriculum, but also school capacity to provide learning experience for the learners, as well as students' ability to achieve optimum results. In practice, however, curriculum planners often neglect this diversity. Teachers with their authorized capacity feel 'safe' to be non-active in which they are not supposed to accommodate those diversities. Neither they are to be involved in determining the philosophical views, theories, vision, documentary development, socialization and curriculum implementation, nor to work on standardized regulations that have been nationally and universally stated. This paper is aimed at sharing the information dealing with appropriate approach that has to be done to accommodate the diversity of social, cultural, political affiliation and economic with the standard national curriculum toward the accomplishment of new curriculum in Vocational Bina Nusantara Mandiri School Pariaman. Data were collected through field survey, observation, and interview with teachers as well as school community who contributed to curriculum development.
\end{abstract}

Key Words: Cross-Cultural Approaches, Curriculum, Curriculum Development, Teacher's Ability

\begin{abstract}
Abstrak: Para pengembang kurikulum sering mengabaikan keragaman sosial, budaya, aspirasi politik dan kemampuan ekonomi peserta didik, pada hal keragaman itu berpengaruh langsung terhadap kemampuan guru dalam melaksanakan kurikulum, kemampuan sekolah dalam menyediakan pengalaman belajar dan kemampuan peserta didik berproses mengolah informasi menjadi hasil belajar. Guru sebagai pemegang otoritas lebih "nyaman" berada pada posisi non aktif untuk mengakomodir keragaman tersebut dan pada tataran penentuan filsafat, teori, visi, pengembangan dokumen, sosialisasi dan pelaksanaan kurikulum bekerja pada aturan-aturan baku yang telah ditetapkan secara nasional dan universal. Makalah ini bertujuan untuk memberikan informasi pendekatan yang akan dilakukan untuk mengakomodir antara keragaman sosial, budaya, aspirasi politik dan kemampuan ekonomi peserta didik dengan kurikulum acuan nasional yang baku untuk pengembangan dan penyempurnaan kurikulum serta langkah langkah yang akan ditempuh pada satuan pendidikan di Sekolah Menengah Kejuruan Plus Bina Nusantara Mandiri Pariaman. Data diperoleh berdasarkan kunjungan lapangan dengan pengamatan dokumen dan wawancara terhadap guru dan perangkat sekolah yang terkait dengan pengembangan kurikulum.
\end{abstract}

Kata Kunci: Pendekatan Lintas-Budaya, Kurikulum, Penyempurnaan Kurikulum, Kemampuan Guru

\section{PENDAHULUAN}

Pengembangan dan penyempurnaan kurikulum, bukanlah suatu pekerjaan mudah. Keragaman sosial, budaya, aspirasi politik, dan kemampuan ekonomi memberikan tekanan yang sama, kalau tidak dapat dikatakan lebih kuat dibandingkan perbedaan filosofi, visi, dan teori yang dianut para pengambil keputusan mengenai kurikulum. Perbedaan filosofi, visi, dan teori para pengambil keputusan seringkali dapat diselesaikan melalui jenjang otoritas yang dimiliki seseorang walaupun dilakukan dalam suatu proses deliberasi yang paling demokratis sekali pun. Ketika perbedaan filosofi, visi, dan teori itu terselesaikan maka proses pengembangan dokumen kurikulum dapat dilakukan dengan mudah. Tim yang direkrut adalah tim yang diketahui memiliki filosofi, visi, dan teori yang sejalan atau bahkan mereka yang tidak memiliki ketiga kualitas itu tetapi ahli dalam masalah konten yang akan dikembangkan sebagai konten kurikulum.

Perbedaan sosial, budaya, aspirasi politik, dan kemampuan ekonomi adalah suatu realita masyarakat dan bangsa Indonesia. Realita tersebut memang berposisi sebagai 
objek periferal dalam proses pengembangan kurikulum nasional. Posisi sebagai objek ini tidak menguntungkan karena ia seringkali diabaikan oleh para otoritas pengembang kurikulum. Anehnya, kedudukannya yang menjadi objek berubah menjadi subjek dan penentu dalam implementasi kurikulum tetapi tetap tidak dijadikan landasan ketika guru mengembangkan kurikulum. Padahal keragaman itu berpengaruh langsung terhadap kemampuan guru dalam melaksanakan kurikulum, kemampuan sekolah dalam menyediakan pengalaman belajar, dan kemampuan siswa dalam berproses dalam belajar serta mengolah informasi menjadi sesuatu yang dapat diterjemahkan sebagai hasil belajar. Artinya, keragaman itu menjadi suatu variabel bebas yang memiliki kontribusi sangat signifikan terhadap keberhasilan kurikulum baik sebagai proses (curriculum as observed, curriculum as experienced, curriculum as implemented, curriculum as reality) tetapi juga kurikulum sebagai hasil.

Posisi keragaman sebagai variabel bebas memang berada pada tataran sekolah dan masyarakat di mana suatu kurikulum dikembangkan dan diharapkan menjadi pengubah yang tangguh sesuai dengan kebutuhan masyarakat yang dapat diperkirakan (perceived needs of a society). Secara nyata pengaruh tersebut berada pada diri guru yang bertanggungjawab terhadap pengembangan kurikulum dan pada siswa yang menjalani kurikulum. Dengan perkataan lain, pengaruh tersebut berada pada tataran yang tak boleh diabaikan sama sekali di mana studi kurikulum memperlihatkan kerentanan, dan kemungkinan besar kurikulum berubah atau bahkan berbeda sama sekali dengan apa yang telah direncanakan dan diputuskan (Waring, 1982). Oleh karena itu,

keragaman sosial, budaya, ekonomi, dan aspirasi politik harus menjadi faktor yang diperhitungkan dan dipertimbangkan dalam penentuan filsafat, teori, visi, pengembangan dokumen, sosialisasi kurikulum, dan pelaksanaan kurikulum.

Sekolah Menengah Kejuruan Plus Bina Nusantara Mandiri (SMK Plus BNM) Pariaman merupakan satu dari ribuan SMK yang ada di Indonesia, memiliki 3 (tiga) program studi, yaitu; Usaha Jasa Pariwisata, Administrasi Perkantoran dan Akuntansi, serta bertujuan:

1. Menyiapkan siswa untuk memasuki lapangan kerja serta mengembangkan sikap profesional.

2. Menyiapkan siswa agar mampu memilih karir, mampu berkompetisi dan mampu mengembangkan diri.

3. Menyiapkan tenaga kerja tingkat menengah untuk mengisi kebutuhan dunia usaha dan perkantoran pada saat ini maupun yang akan datang.

4. Menyiapkan tamatan agar menjadi warga negara yang produktif, adaptif dan kreatif (SMK Plus BNM Pariaman, 2005)

Sedangkan dari segi kurikulum, disusun dengan berpedoman pada saat pendirian awal sekolah tersebut, sesuai dengan Surat Keputusan Dirjen Dikdasmen Nomor 282/C/Kep/M/1994, tentang pelaksanaan kurikulum SMK pada butir 8 yang berkaitan dengan pembukaan program studi baru pada SMK swasta, serta direvisi sesuai dengan model Silabus dan Rencana Pelaksanaan Pembelajaran Kurikulum Tingkat Satuan Pendidikan SMK (Silabus KTSP SMK dan RPP KTSP SMK).

\section{KURIKULUM DAN LANDASAN PE- NGEMBANGAN}

Pengembangan kurikulum tingkat satuan pendidikan (KTSP) yang beragam mengacu pada standar nasional pendidikan untuk menjamin pencapaian tujuan pendidikan nasional. Standar nasional pendidikan terdiri atas standar isi, proses, kompetensi lulusan, tenaga kependidikan, sarana dan prasarana, pengelolaan, pembiayaan dan penilaian pendidikan. Dua dari delapan standar pendidikan nasional pendidikan tersebut, yaitu standar isi (SI) dan standar kompetensi lulusan (SKL) merupakan acuan utama bagi satuan pendidikan dalam mengembangkan kurikulum.

Sudah sejak lama para ahli pendidikan dan kurikulum menyadari bahwa kebudayaan adalah salah satu landasan pengembangan kurikulum (Taba, 1962) di samping landasan lain seperti perkembangan masyarakat, ilmu 
pengetahuan, teknologi, politik, ekonomi. Ki Hajar Dewantara (1946) menyatakan bahwa kebudayaan merupakan faktor penting sebagai akar pendidikan suatu bangsa. Ahli kurikulum lain seperti Print (1993) menyatakan pentingnya kebudayaan sebagai landasan bagi kurikulum dengan mengatakan bahwa kurikulum is a construct of that culture. Kebudayaan merupakan keseluruhan totalitas cara manusia hidup dan mengembangkan pola kehidupannya sehingga ia tidak saja menjadi landasan di mana kurikulum dikembangkan tetapi juga menjadi target hasil pengembangan kurikulum. Langrall, Cynthia W., (2006) melihat bahwa kebudayaan berfungsi dalam dua perspektif yaitu eksternal dan internal, lebih lanjut dijelakan:

The environment of the curriculum is external insofar as the social order in general establishes the milieu within which the schools operate; it is internal insofar as each of us carries around in our mind's eye models of how the schools should function and what the curriculum should be. The external environment is full of disparate but overt conceptions about what the schools should be doing. The internal environment is a multiplicity of largely unconscious and often distorted views of our educational realitiesfor,as individuals, we caught by our own cultural mindsets about what should be, rather than by a recognition of our swiftly changing, current realities.

Kedudukan kebudayaan dalam suatu proses kurikulum teramat penting tetapi dalam proses pengembangan seringkali para pengembang kurikulum kurang memperhatikannya. Dalam realita proses pengembangan kurikulum sering diwarnai oleh pengaruh pandangan para pengembang terhadap perkembangan ilmu dan teknologi. Pertimbangan mengenai kebutuhan peserta didik dan masyarakat sering dijawab dengan jawaban mengenai adanya perkembangan dalam ilmu pengetahuan. Oleh karena, itu kedudukan yang penting dari kebudayaan terabaikan pula seperti halnya landasan lainnya yang harus diperhatikan dalam pengembangan kurikulum. Secara intrinsik, filosofi, visi, dan tujuan pendidikan, para pengembang kurikulum sangat dipengaruhi oleh latar belakang pendidikan, pandangan hidup, dan keyakinan hidupnya. Faktor penentu filosofi, visi, dan tujuan tersebut sangat ditentukan oleh akar budaya dan kebudayaan dari para pengembang kurikulum. Ini yang dikatakan oleh Langrall, Cynthia W., (2006) dengan pernyataan: we are largely unaware of the numerous, culturally formed qualities that characterize our behaviour. Oleh karena itu, baik secara langsung maupun tidak langsung, proses internal pengembangan suatu kurikulum sangat pula dipengaruhi oleh kebudayaan para pengembang kurikulum.

Sekaitan dengan hal di atas, budaya lokal masyarakat Pariaman sudah seharusnya diakomodir dalam pengembangan kurikulum di SMK Plus ini, terutama bagi program studi Usaha Jasa Pariwisata, namun yang terlihat hanya kurikulum yang berorientasi nasional yang masih dipakai dan diyakini masih belum sesuai dengan budaya lokal. Para pengembang kurikulum belum memahami atau takut melakukan perombakan kurikulum yang seharusnya disesuaikan dengan budaya lokal, budaya menerima perintah serta menerima instruksi masih terlihat secara menyeluruh pada semua jenjang pengambilan keputusan.

Selanjutnya landasan lain yang diperlukan dalam pengembangan kurikulum adalah teori belajar yaitu teori tentang bagaimana siswa belajar. Selama ini, orang berbicara tentang teori belajar yang dikembangkan terutama dari psikologi. Teori belajar seperti yang dikenal dalam literatur dikembangkan dari berbagai aliran dan teori dalam psikologi seperti behaviorrisme (stimulus-response, conditioning, operant conditioing, modelling, dan sebagainya), kognitif (skemata, akomodasi, dan asimilasi dari Piaget, meaningful learning dari Ausubel, dan sebagainya). Teori belajar yang dikembangkan dari pandangan ini tentu saja sangat berguna dan dikembangkan berdasarkan hasil studi yang mendalam dan dalam waktu yang cukup panjang.

Anehnya, teori belajar yang dikembangkan berdasarkan pandangan 
psikologi ini sering memiliki asumsi bahwa siswa belajar dalam suatu situasi yang value free atau lebih tepat dikatakan cultural and societal free. Teori-teori belajar itu tidak memperhitungkan bahwa siswa yang belajar adalah suatu pribadi yang hidup dan bereaksi terhadap stimulus (apakah dikembangkan berdasarkan teori behaviorisme atau kognitif) yang tidak dapat dilepaskan dari lingkungan sosial dan budaya di mana ia hidup. Dalam bukunya yang berjudul Sociocultural origins of achievement, Maehr (1974) mengatakan bahwa keterkaitan antara kebudayaan dan bahasa, kebudayaan dan persepsi, kebudayaan dan kognisi, kebudayaan dan keinginan berprestasi, serta kebudayaan dan motivasi berprestasi merupakan faktor-faktor yang berpengaruh terhadap belajar siswa.

Lebih lanjut, studi Burnett (1994) menunjukkan bahwa proses belajar siswa yang dikembangkan melalui pertimbangan budaya menunjukkan hasil yang lebih baik. Hal itu terjadi karena seperti yang dikemukakan oleh Oliver dan Howley (1992) kebudayaan governs how people share information and knowledge, as well as how they construct meaning. Peran kebudayaan yang kuat dalam upaya seseorang memahami lingkungan dan belajar dikemukakan oleh Delpit (1996) dengan mengatakan we all interpret behaviors, information, and situation through our own cultural lenses; these lenses operate involuntarily, below the level of conscious awareness, making it seems that our own view is imply, the way it is. Oleh karena itu, sudah saatnya untuk memperhitungkan faktor kebudayaan sebagai landasan penting dalam menentukan komponen tujuan, materi, proses, dan evaluasi suatu kurikulum, dan kegiatan belajar siswa. Konsekuensinya, para pengembang kurikulum di tingkat pusat, daerah, dan sekolah harus memanfaatkan kebudayaan sebagai landasan pengembangan secara lebih sungguh-sungguh dan sistematis.

Hasil pengamatan di SMK Plus BNM Pariaman yang memusatkan perhatian pada topik di atas menghasilkan bahwa belum ada guru atau perangkat sekolah yang mengerti dan memahami kurikulum yang berbasis budaya ini dan kontribusinya terhadap hasil belajar.
Pembelajaran yang dilakukan hanyalah sebatas aturan-aturan baku yang diterima pada tahun tahun sebelumnya, tanpa ada orang atau kelompok yang berani melakukan perubahan, mengajar lebih bernuansa menjalankan sistem mesin yang baku, dengan guru sebagai pusat kendali, sehingga classroom change dari teaching ke learning belum ditemui.

\section{PENDEKATAN LINTAS BUDAYA UNTUK KURIKULUM}

Indonesia adalah negara yang kaya dengan budaya seperti dinyatakan dalam motto nasional "Bhinneka Tunggal Ika". Kenyataan ini diakui pula oleh seorang ahli sejarah Amerika, Wolpert (1965) yang mengatakan bahwa: more pluralistic in every respect than any other on earth except, perhaps, Indonesia. Oleh karena itu, apabila kebudayaan adalah salah satu landasan kuat dalam pengembangan kurikulum maka proses pengembangan kurikulum di Indonesia harus pula memperhatikan keragaman kebudayaan yang ada. Artinya, pendekatan lintasbudaya dalam pengembangan kurikulum di Indonesia adalah suatu keharusan yang tak dapat diabaikan lagi.

Pemberlakuan Undang-Undang nomor 22 tahun 1999 tentang otonomi daerah

tidak akan secara langsung menjadikan pendekatan lintasbudaya berlaku dalam pengembangan kurikulum di Indonesia. Undang-undang tersebut yang memberikan wewenang pengelolaan pendidikan kepada pemerintah daerah mungkin saja akan menghasilkan berbagai kurikulum sesuai dengan visi, misi, dan persepsi para pengembang kurikulum di daerah, tetapi bukan tidak mungkin bahwa kurikulum yang dikembangkan tersebut tidak dikembangkan berdasarkan pendekatan budaya apalagi pendekatan lintasbudaya. Kurikulum yang dihasilkan mungkin saja dikembangkan berdasarkan pendekatan budaya tetapi tidak berarti langsung menjadi kurikulum yang berdasarkan pendekatan lintasbudaya. Kurikulum yang menggunakan pendekatan lintasbudaya haruslah dikembangkan dengan 
kesadaran dan pemahaman yang mendalam tentang pendekatan ini.

Andersen dan Cusher

mengatakan bahwa lintasbudaya adalah pendidikan mengenai keragaman kebudayaan. Definisi ini lebih luas dibandingkan dari yang dikemukakan di atas. Meskipun demikian posisi kebudayaan masih sama dengan apa yang dikemukakan dalam definisi di atas yaitu keragamaan kebudayaan menjadi sesuatu yang dipelajari; jadi berstatus sebagai objek studi. Dengan perkataan lain, keragaman

kebudayaan menjadi materi pelajaran yang harus diperhatikan para pengembang kurikulum.

Pengertian pendidikan lintasbudaya seperti di atas tentu terbatas dan hanya berguna bagi para pengembang kurikulum dalam satu aspek saja yaitu dalam proses mengembangkan konten kurikulum. Pengertian itu tidak dapat membantu para pengembang kurikulum dalam menggunakan kebudayaan, dan dalam konteks ini menggunakan kenyataan budaya sebagai landasan dalam mengembangkan visi, misi, tujuan, dan berbagai komponen kurikulum. Dengan demikian, pengertian lain mengenai pendekatan lintasbudaya harus dirumuskan agar dapat digunakan dalam pengembangan kurikulum. Untuk itu, maka definisi pendekatan lintasbudaya tersebut haruslah membantu para pengembang kurikulum dalam mengembangkan prinsip-prinsip kurikulum, materi kurikulum (Ansyar: 2008). Artinya, pengertian pendekatan lintasbudaya kurikulum harus dapat mengakomodasi perbedaan kultural peserta didik, memanfaatkan kebudayaan itu sebagai sumber konten dan memanfaatkannya sebagai titik berangkat untuk pengembangan kebudayaan itu sendiri, pemahaman terhadap kebudayaan orang lain, toleransi, membangkitkan semangat kebangsaan siswa yang berdasarkan "bhinneka tunggal ika", mengembangkan perilaku yang etis, dan yang juga tak kalah pentingnya adalah dapat memanfaatkan kebudayaan pribadi siswa sebagai bagian dari entry-behavior siswa sehingga dapat menciptakan "kesempatan yang sama bagi siswa untuk berprestasi" (Boyd, 1989).
Sebagai pendekatan dalam pengembangan kurikulum maka pendekatan lintasbudaya untuk kurikulum diartikan sebagai suatu prinsip yang menggunakan keragaman kebudayaan peserta didik dalam mengembangkan filosofi, misi, tujuan, dan komponen kurikulum, serta lingkungan belajar sehingga siswa dapat menggunakan kebudayaan pribadinya untuk memahami dan mengembangkan berbagai wawasan, konsep, keterampilan, nilai, sikap, dan moral yang diharapkan.

Pendekatan lintasbudaya untuk pengembangan kurikulum di Sekolah Menengah Kejuruan Plus Bina Nusantara Mandiri Pariaman, untuk mencapai sasaran seperti kajian di atas di atas nampaknya belum ada, karena menurut para pengembang kurikulum pada tataran sekolah tersebut menilai bahwa para siswa mulai dari kelas X s/d kelas XII rata rata berasal dari daerah yang sama, sehingga kebutuhan akan hal ini belum ada.

\section{KURIKULUM LINTAS BUDAYA MASA MENDATANG}

Proses pengembangan kurikulum haruslah meliputi tiga dimensi kurikulum yaitu kurikulum sebagai ide, kurikulum sebagai dokumen, dan kurikulum sebagai proses. Ketiga dimensi kurikulum ini berkaitan satu dengan lainnya dan kurikulum sebagai proses dilaksanakan dengan berbagai kebijakan kurikulum. Kebijakan-kebijakan tersebut merupakan operasionalisasi kurikulum sebagai ide dan kurikulum sebagai dokumen.

Pengembangan ide berkenaan dengan penentuan filosofi kurikulum, model kurikulum yang digunakan, pendekatan dan teori belajar yang digunakan, pendekatan/model evaluasi hasil belajar. Pengembangan dokumen berkenaan dengan pengembangan kurikulum sebagai dokumen tertulis yang didasarkan pada ide yang sudah ditetapkan sebelumnya. Secara teknis pengembangan kurikulum sebagai dokumen berkenaan dengan keputusan

tentang informasi dan jenis dokumen yang akan dihasilkan, bentuk/format GBPP, dan komponen kurikulum yang harus dikembangkan. Apakah kurikulum sebagai ide dan kurikulum sebagai 
dokumen akan dijadikan satu atau dua dokumen yang terpisah harus pula ditentukan. Apapun keputusan tentang itu antara pengembangan kurikulum sebagai ide dan kurikulum sebagai dokumen diperlukan sosialisasi agar terjadi kesinambungan buah pemikiran para pengambil keputusan kurikulum dengan para pengembang teknis.

Pengembangan kurikulum sebagai proses terjadi pada unit pendidikan atau sekolah. Pengembangan ini haruslah didahului oleh sosialisasi agar para pengembang (guru) dapat mengembangkan kurikulum dalam bentuk rencana pelajaran/satuan pelajaran, proses belajar di kelas, dan evaluasi sesuai dengan prinsip lintasbudaya kurikulum. Sosialisasi

yang dilakukan haruslah dilakukan orang-orang yang terlibat paling tidak dalam proses pengembangan kurikulum sebagai dokumen apabila orang yang terlibat dalam pengembangan ide tidak mungkin secara teknis. Jika terjadi perluasan tim sosialisasi maka anggota tim yang baru haruslah yang sepenuhnya faham dengan karakteristik kurikulum lintasbudaya ini. Pada fase ini, target utama adalah para guru paham dan berkeinginan untuk mengembangkan kurikulum lintasbudaya dalam kegiatan belajar yang menjadi tanggungjawabnya.

Pengembangan kurikulum sebagai proses sangat ditentukan oleh guru. Baik dalam konteks sentralisasi maupun dalam konteks otonomi, peran guru tersebut tetap sama, mereka adalah pengembang kurikulum pada tataran empirik yang langsung berkaitan dengan siswa. Oleh karena itu, jika kurikulum yang dikembangkan tidak sesuai dengan apa yang sudah ditentukan dalam kurikulum sebagai ide dan kurikulum sebagai dokumen, maka kurikulum sebagai proses bukan lagi kelanjutan dari keduanya. Dalam konteks yang lebih ekstrim, kurikulum sebagai proses dapat merupakan kurikulum yang berbeda sama sekali dengan keduanya. Pengetahuan, pemahaman, dan sikap, serta kemauan guru terhadap

kurikulum lintasbudaya akan sangat menentukan keberhasilan pelaksanaan kurikulum sebagai proses.
Ada empat hal yang harus diperhatikan guru dalam mengembangkan kurikulum sebagai proses, yaitu: (1) posisi siswa sebagai subjek dalam belajar, (2) cara belajar siswa yang ditentukan oleh latar belakang budayanya, (3) lingkungan budaya mayoritas masyarakat dan pribadi siswa adalah entry behavior kultural siswa, (4) lingkungan budaya siswa adalah sumber belajar.

Selanjutnya kurikulum untuk SMK dapat dikembangkan berdasarkan pendekatan teknologi/vokasional. Meskipun demikian, sebagaimana perlu ada revisi terhadap filsafat progresif dan rekonstruksi sosial yang digunakan, diperlukan pula revisi terhadap tujuan, materi, proses belajar, dan evaluasi yang dikembangkan. Keterampilanketerampilan dalam bidang teknologi tertentu dan vokasional tertentu yang dibutuhkan oleh suatu

lingkungan budaya dijadikan konten utama kurikulum. Dalam proses belajar yang dikembangkan kurikulum 2004 posisi siswa adalah sebagai dependent variable yang sangat tergantung dari metode yang digunakan guru dan bukan sebagai orang yang belajar untuk mencapai kualitas yang dinyatakan dalam tujuan.

Pengembangan kurikulum sebagai dokumen menyangkut pengembangan berbagai komponen kurikulum seperti tujuan, konten, pengalaman belajar, dan evaluasi. Tujuan adalah kualitas yang diharapkan dimiliki siswa yang belajar berdasarkan kurikulum tersebut. Pengembangan kurikulum lintasbudaya harus terbuka pada berbagai pandangan dan

pendekatan perumusan tujuan. Rumusan yang berdasarkan pandangan behaviorisme dan menghendaki rumusan tujuan yang terukur sudah tidak dapat dipertahankan lagi. Para pengembang kurikulum harus dapat membuka diri bahwa tidak semua kualitas manusia dapat dinyatakan terukur berdasarkan kriteria tertentu. Ada tujuan-tujuan yang dapat diukur dan bersifat dapat dikuasai dalam satu atau dua pengalaman belajar, tetapi ada juga tujuan yang baru tercapai dalam waktu belajar yang lebih panjang. Oleh karena itu, pemaksaan suatu pendekatan dalam pengembangan tujuan tidak dapat dipertahankan lagi. 


\section{SIMPULAN}

Berdasarkan hasil pengamatan langsung terhadap satuan pendidikan pada SMK Plus BNM Pariaman, maka penulis memberikan informasi kepada para penanggung jawab pengembang kurikulum sebagai berikut:

a. Kurikulum yang menggunakan pendekatan pengembangan lintasbudaya haruslah didasarkan pada prinsip:

- Keragaman budaya menjadi dasar dalam menentukan filsafat, teori, model, dan hubungan sekolah dengan lingkungan sosial-budaya setempat;

- Keragaman budaya menjadi dasar dalam mengembangkan berbagai komponen

kurikulum seperti tujuan, konten, proses, dan evaluasi;

- Budaya di lingkungan unit pendidikan adalah sumber belajar dan objek

studi yang harus dijadikan bagian dari kegiatan belajar siswa; dan

- Kurikulum berperan sebagai media dalam mengembangkan kebudayaan daerah

dan kebudayaan nasional.

b. Pendekatan lintas budaya untuk pengembangan kurikulum di SMK Plus Bina Nusantara Mandiri Pariaman belum dilakukan, karena para siswa mulai dari kelas X s/d kelas XII rata rata berasal dari daerah yang sama, sehingga kebutuhan tentang hal ini belum diberikan prioritas.

c. Belum ada guru atau perangkat sekolah yang mengerti dan memahami kurikulum lintasbudaya ini dan kontribusinya terhadap hasil belajar. Pembelajaran yang dilakukan hanyalah sebatas aturan aturan baku yang diterima pada tahun tahun yang lalu, tanpa ada orang atau kelompok yang berani melakukan perubahan, mengajar lebih bernuansa menjalankan sistem mesin yang baku, dengan guru sebagai pusat kendali, sehingga classroom change dari teaching ke learning belum ditemui.

d. Pengembangan kurikulum masa depan yang berdasarkan pendekatan lintasbudaya dapat dilakukan berdasarkan langkah-langkah sebagai berikut:

a. Mengubah filosofi kurikulum dari yang berlaku seragam seperti saat ini kepada filosofi yang lebih sesuai dengan tujuan, misi, dan fungsi setiap jenjang pendidikan dan unit pendidikan. Untuk tingkat pendidikan dasar dan menengah, filosofi konservatif seperti esensialisme dan perenialisme haruslah dapat diubah ke filosofi yang lebih menekankan pendidikan sebagai upaya mengembangkan kemampuan kemanusiaan peserta didik baik sebagai individu maupun sebagai anggota masyarakat, bangsa, dan dunia. Filosofi kurikulum yang progresif seperti humanisme, progresivisme, dan rekonstruksi sosial dapat dijadikan landasan pengembangan kurikulum.

b. Teori kurikulum tentang konten (curriculum content) haruslah berubah dari teori yang mengartikan konten sebagai aspek substantif yang berisikan fakta, teori, generalisasi kepada pengertian yang mencakup pula nilai, moral, prosedur, proses, dan keterampilan yang harus dimiliki generasi muda.

c. Teori belajar yang digunakan dalam kurikulum masa depan yang memperhatikan keragaman sosial, budaya, ekonomi, dan politik tidak boleh lagi hanya mendasarkan diri pada teori psikologi belajar yang bersifat individualistik dan menempatkan siswa dalam suatu kondisi value free, tetapi harus pula didasarkan pada teori belajar yang menempatkan siswa sebagai makhluk sosial, budaya, politik, dan hidup sebagai anggota aktif masyarakat, bangsa dan dunia.

d. Proses belajar yang dikembangkan untuk siswa haruslah pula berdasarkan proses yang memiliki tingkat isomorphism yang tinggi dengan kenyataan sosial. Artinya, proses belajar yang mengandalkan siswa belajar secara individualistis dan bersaing secara kompetitif individualistis harus ditinggalkan dan diganti dengan 
cara belajar berkelompok dan bersaing secara kelompok dalam suatu situasi positif. Dengan cara demikian maka perbedaan antar-individu dapat dikembangkan sebagai suatu kekuatan kelompok dan siswa terbiasa hidup dengan berbagai keragaman budaya, sosial, intelektualitas, ekonomi, dan aspirasi politik.

e. Evaluasi yang digunakan haruslah meliputi keseluruhan aspek kemampuan dan kepribadian peserta didik, sesuai dengan tujuan dan konten yang dikembangkan. Alat evaluasi yang digunakan haruslah beragam sesuai dengan sifat tujuan dan informasi yang ingin dikumpulkan. Penggunaan alternative assessment (portfolio, catatan observasi, wawancara) dapat digunakan.

\section{DAFTAR RUJUKAN}

Andersen, R. dan Cusher, K. 1994. Multicultural and intercultural studies. Sydney: Prentice-Hall

Ansyar 2008. Pendidikan Berbasis Kompetensi: Implikasi pada Kurikulum dan Pembelajaran. Universitas Negeri Padang; Makalah

Banks, J. 1993. Multicultural education: historical development, dimensions, and practice. Review of Research in Education.

Burnett, G. 1994. Varieties of multicultural education: an introduction. Eric Clearinghouse on Urban Education.

Cooper, H. \& Dorr, N. 1995. Race comparisons on need for achievement: a meta analytic alternative to Graham's Narrative Review. Review of Educational Research.
Delpit, L. 2008. Thoughts on Language and Culture in the Classroom. New York: The New Press. Reviewed by Virginia S. Loh, University of San Diego and National University.

Depdiknas. 2007. Model Rencana Pelaksanaan Pembelajaran Kurikulum Tingkat Satuan Pendidikan SMK. Jakarta; Depdiknas

Depdiknas. 2007. Model Silabus Kurikulum Tingkat Satuan Pendidikan SMK. Jakarta; Depdiknas

Dewantara, K.H. 1946. Dasar-dasar pembaharuan pengajaran, dalam Karya Ki Hajar Dewantara Bagian Pertama: Pendidikan. Yogyakarta

Langrall, C.W. 2006. Teachers Engaged in Research: Inquiry into Mathematics Classrooms, Publishing. Reviewed by Christopher Johnston, George Mason University

Oliver, J.P. and Howley, C. 1992. Charting new maps: multicultural education in rural schools. ERIC Clearinghouse on Rural Education and Small School.

Print, M. 1993. Curriculum Development and Design. St. Leonard: Allen \& Unwin Pty, Ltd.

SMK Plus BNM. 2005. Proposal pendirian Sekolah Menengah Kejuruan Plus Bina Nusantara Mandiri Pariaman. Pariaman; tidak diterbitkan.

Undang-undang nomor 22 tahun 2009 tentang Otonomi Daerah 